\title{
Woodland loss and restoration in a savanna park: a 20-year experiment
}

\author{
David Western* and David Maitumo \\ Wildife Conservation Society and African Conservation Centre, Box 62844, Nairobi, Kenya
}

\begin{abstract}
Woodland loss is a major cause of biodiversity decline in African savanna parks. Decisions about whether remedial steps are possible and warranted depend on the cause. Climate, fire, elephants and human impact, often in combination, have been cited as major causes. The almost complete extinction of woodland in Amboseli National Park since 1950 has been at the centre of such debate. A 20-year study based on an experimental design to test overgrazing, pathogen, climate and elephant browsing theories of woodland loss was established in 1981. The experiment showed that elephants alone are preventing regeneration. Based on the outcome of the experiment, a woodland refuge was restored in the centre of the park to maintain biodiversity and demonstrate the management prospects for habitat restoration. A strong interaction of elephants and pastoralists, played out across the ecosystem over many decades, probably accounts for the habitat mosaic and high biological diversity of the ecosystem prior to the establishment of the national park. The restoration of biodiversity in the park will therefore depend on mimicking the shifting mosaic of habitats created by their interaction.
\end{abstract}

Key words: biodiversity, conservation, elephant woodland dynamics, pastoralists, restoration, savannas

\section{Résumé}

La perte de zones boisées est une des causes majeures du déclin de la biodiversité dans les parcs de savane africains. Savoir s'il est possible de prendre des mesures pour y remédier et si elles seraient garanties dépend des causes impliquées. Le climat, les feux, les éléphants et l'impact humain, combinés le plus souvent, ont été cités comme des causes principales. La disparition quasi complète des zones

*Correspondence: Tel.: +254 2089 1360; E-mail: dwestern@ africaonline.co.ke boisées du Parc National d'Amboseli depuis 1950 est au centre d'un tel débat. Une étude de plus de vingt ans a été lancée en 1981, basée sur un projet expérimental destiné à tester les théories impliquant le surpâturage, les agents pathogènes, le climat et les prélèvements par les éléphants dans la perte de la forêt. L'expérience a montré que ce sont les éléphants seuls qui empêchent la régénération. Suite aux résultats de l'étude, un refuge forestier a èté restauré au centre du parc pour maintenir la biodiversité et montrer quelles pourraient être les perspectives de restauration de l'habitat en cas de gestion adéquate. La forte interaction entre les éléphants et les pasteurs qui a duré de nombreuses décennies à travers tout l'écosystème explique probablement la mosaïque de l'habitat et la grande biodiversité de l'écosystème avant la crèation du parc national. La restauration de la biodiversité dans le parc dépendra donc de la façon dont on pourra reproduire la mosaïque changeante des habitats créée par leur interaction.

\section{Introduction}

The large-scale loss of woodlands in savanna parks has been widely documented throughout eastern and southern Africa over the last 40 years (Laws, Parker \& Johnstone, 1975; Barnes, 1983; Dublin, 1995). Woodland loss can affect many habitat-dependent taxa, raising the prospects of an overall loss of biodiversity in protected areas (Cumming et al., 1997). The widespread destruction of woodlands due to agriculture and other human activity (Huntley, 1982) throughout the savannas makes the biodiversity losses within parks all the more troubling.

For several decades Amboseli National Park in southern Kenya has been at the heart of debates over whether the woodland loss is natural or not, the implications for biodiversity and whether the trend is reversible. Concern was first raised over the loss of Amboseli's elegant fever tree (Acacia xanthophloea) in the mid-1960s. The loss took on 
broader significance when it was shown to foreshadow a broad shift from woodland to xeric scrub habitat (Western \& van Praet, 1973; Western, 1973), several extinctions and an overall loss of biodiversity (Western, 1989).

Several theories have been advanced for the loss of Amboseli woodlands and associated habitat change, ranging from livestock overgrazing to elephant compression and climate change (Western \& van Praet, 1973). Each theory assumes a different cause and, by inference, remedy. These include no intervention in the case of climate change to destocking in the case of overuse by livestock and elephants. Here we report on long-term experiments on the causes of the virtual extinction of woodlands. The experiments were designed to distinguish between these theories and show whether woodlands can be restored. We also report on the successful establishment of a woodland refuge in the centre of the park based on the outcome of the experiments.

\section{Background to experiments}

Several theories have been advanced for the woodland changes in Amboseli, each relevant to the overall research design.

\section{Overgrazing theory}

This view, widely aired by conservationists in the popular press in the late 1960s (Anonymous, 1963), holds that the woodland decline dates from the 1961 when livestock invaded the reserve and overgrazed the fragile woodland habitat (Anonymous, 1963).

\section{Pathogen/pest theory}

This theory was based on the observation that dead and dying trees were usually riddled with holes of wood-boring beetles. Although ruled out by Western \& van Praet (1973), it is tested here for the sake of completeness.

\section{Climatic-related theories}

Two climate-related theories, both invoking rainfall fluctuations, have been invoked to explain the woodland loss.

Salinity theory. Western \& van Praet (1973) concluded from a detailed study of woodland loss between 1970 and 1972 that climate-driven salinity changes were the primary cause. In their view, a rainfall increase, linked to a regional climatic shift, had raised the water table of the ancient Pleistocene alkaline lakebed sufficient to salinize the roots of fever trees.

Demographic theory. Young \& Lindsay (1988) speculated that episodic high rainfall caused pulses of seedling growth leading to even-aged trees that matured and died over several decades.

\section{Overbrowsing theory}

Laws (1970) suggested that elephants were destroying the Amboseli woodlands, based on his studies of woodland loss in Queen Elizabeth National Park in Uganda and Tsavo National Park in Kenya.

The overgrazing and overbrowsing theories are two aspects of a larger body of concern with the impact of locally overabundant large mammals (Jewell \& Holt, 1981). Species other than livestock and elephants may well have an impact on the woodlands. We have therefore expanded the scope of the experiments to include all large herbivores and invertebrates.

In 1981, we set up a comprehensive series of experiments to test all four theories experimentally.

\section{Study area}

The study area has been detailed in several publications, including Western \& Sindiyo (1972), Western (1973), Western \& Lindsay (1984) and Lindsay (1994). The dynamics of the fever tree woodlands, described in Western (1973) and Western \& van Praet (1973), fall within an ecological study of Amboseli region that we have conducted continuously since 1967 .

Amboseli is a shallow basin defined by a dried out Pleistocene lake lying $1200 \mathrm{~m}$ a.s.l. at the northern foot slope of Kilimanjaro on the Kenya-Tanzania border. The surrounding area is bushed grassland with an annual rainfall of 250-300 mm distributed in two seasons, October-December and March-May. The basin soils are alkaline and locally saline (Western, 1973). The dominant vegetation in the basin is alkaline grassland in the centre and north, and before their disappearance since the 1960s, fever tree (Acacia xanthophloea) woodland with a bushed understory of Salvadora persica, Azima tetracantha and Sueada monoica to the south. Three large and many small swamps fed by aquifers from Kilimanjaro spread across the basin within the woodlands. The Amboseli basin is the dry 
season concentration area for large mammals and pastoral Maasai migrating seasonally over the $8500 \mathrm{~km}^{2}$ Amboseli ecosystem (Western, 1973).

The most conspicuous ecological change since the 1960s has been the loss of fever tree woodlands and replacement by low scrub dominated by Sueada monoica and Salvadora persica. The loss of the elegant fever trees has been a matter of great concern to conservationists since the 1960s. Yet another obvious change is the collapse of seasonal elephant migrations following heavy poaching in the early 1970s. The migrations of other species were unaffected (Western, 1994). The collapse of the elephant migrations led to sharp rise in the park population (Western \& Lindsay, 1984).

An area of $388 \mathrm{~km}^{2}$ within the basin was set aside as Amboseli National Park in 1974, partly due to international pressures to remove the pastoral Maasai who were thought to be destroying the woodlands through overgrazing by their livestock.

\section{Methods}

For ease of monitoring, the site selected for the experiment lay between David Western's research house and the Ol Tukai Lodge. The site was one of eighteen studied in December 1969 by Western \& van Praet (1973) when investigating the causes of woodland loss. It was one of eleven woodland plots classified as moribund and highly saline. Tree canopy cover was $17 \%$ when first measured in 1969. Eighty per cent of all trees were dead or dying and all were fully mature with an average height of $17 \mathrm{~m}$. There was no evidence at that time of any recruitment since 1950 , based on stem diameter and aerial photographs dating back to 1950 (Western, 1973). By 1981, when we set up the experimental plot, all the trees had died and no recruitment had occurred in over 30 years.

Despite the lack of adult recruitment, seedlings were abundant at the experimental site. To ensure that the seedlings were representative of the population at large, we randomly chose 32 plots across the park. Plot sizes varied from 0.0025 to 0.4 ha, depending on the density of seedlings. Seedling density averaged $92 \mathrm{ha}^{-1}$ but showed considerable variation ( $\mathrm{SE}=51$, range $=0-1179$ ). Seedling height, on the other hand, was remarkably uniform across all plots $($ mean $=30.5 \mathrm{~cm}, \mathrm{SE}=3.14$, range $=$ 11-67). The average height of the experimental seedlings in the experimental plot fell within 1.96 standard errors of the population mean for the park.

\section{Phase 1 experiment}

In Phase 1 of the experiment, running from September 1981 to October 1984, we tagged 40 seedlings for study within a $50 \times 50 \mathrm{~m}(0.25 \mathrm{ha})$ plot. Half the seedlings were protected from large herbivores using a $160 \mathrm{~cm}$ wide by $130 \mathrm{~cm}$ deep game barrier to exclude elephants. An inner $1.5 \mathrm{~m}$ fivestrand wire fence was constructed to exclude other species of large ungulates, including impala, zebra, wildebeest and buffalo. The remaining twenty seedlings were exposed to all large herbivores outside the exclosure. We assumed that any recruitment in the exclosure in the absence of recruitment on the control plot would discount climate, soils or pathogens holding back woodland regeneration.

Both the protected and exposed seedlings were randomly assigned to four experimental treatments with five replicates. Using a factorial design, we apportioned treatments on the basis of presence or absence of vertebrate browsers, presence or absence of invertebrate browsers, presence or absence of plant competitors and, lastly, interactions between each of these three factors (Table 1). A light atomized mist spray of Roxion insecticide was applied every 2 weeks to deter invertebrate browsers. We detected no caterpillar or other invertebrate herbivory on sprayed plants, or any observable loss of leaf vigor. Above-ground plant competition was eliminated by regularly clipping the herb-layer to ground level within a meter radius of the experimental seedlings.

For each seedling, height, stem diameter, leaf length, leafiness (an index of leaf area) and signs of herbivory were recorded monthly. Large herbivore browsing was distinguished from invertebrate browsing by stripped-off whole

Table 1 Experimental design for acacia seedling experiments

\begin{tabular}{ll}
\hline Treatment no. & Treatments \\
\hline Outside & \\
1 & $+\mathrm{LH}+\mathrm{C}+\mathrm{HC}$ \\
2 & $+\mathrm{LH}+\mathrm{C}-\mathrm{HC}$ \\
4 & $+\mathrm{LH}-\mathrm{C}+\mathrm{HC}$ \\
3 & $+\mathrm{LH}-\mathrm{C}-\mathrm{HC}$ \\
Inside & \\
1 & $-\mathrm{LH}+\mathrm{C}+\mathrm{HC}$ \\
2 & $-\mathrm{LH}+\mathrm{C}-\mathrm{HC}$ \\
3 & $-\mathrm{LH}-\mathrm{C}+\mathrm{HC}$ \\
4 & $-\mathrm{LH}-\mathrm{C}-\mathrm{HC}$ \\
\hline
\end{tabular}

Each treatment included five randomly assigned replicates $\mathrm{LH}$, large herbivores; C, caterpillars; $\mathrm{HC}$, herb cover. 
leaves and nibbled shoots. Elephants browsed distinctively by stripping off or plucking entire shoots - often the whole seedling - and were easily distinguished from other browsers. Giraffe, which also browse heavily on acacias, were not recorded near the plot throughout the experiment. The death rate among seedlings plucked by elephants was high, although many recovered after several months. We therefore continued to measure the condition of each seedling throughout 3-year phase 1 experiment, whether or not it appeared to have died.

By October 1983, the results of the phase 1 experiment were highly conclusive. Seedlings inside the exclosure were growing so vigorously that the tallest plants had reached $2.8 \mathrm{~m}$ and were beginning to overshadow the slower growing seedlings. We therefore terminated phase 1 experiment for the purposes of looking at the impact and interaction of the three treatments. We nevertheless continued to apply the three treatments until September 1984. By then the seedlings inside the exclosure were too tall to warrant further insect or plant-competitor treatment. From then onwards, we simply monitored the height and stem diameter of all seedlings in and outside the exclosure to see if they reached maturity. Trees inside the exclosure matured, flowered and produced seeds in 1988 , at which point we terminated the experiment. The regeneration was in any event so prolific that it was impossible to measure height and stem diameter through the tangle of thorns.

Phase 2 experiment

In April 1985 we set up phase 2 experiment to distinguish the impact of elephants from all other large herbivores. To do so we tagged 40 seedlings within a $100 \times 100 \mathrm{~m}$ area outside the phase 1 plot. Half the seedlings were protected from elephants by an electric fence, the other half left exposed. The elephant exclosure was a single wire suspended $2 \mathrm{~m}$ above ground on posts set $20 \mathrm{~m}$ apart. A solar electric energizer powered the wire with a $5000 \mathrm{~V}$ current pulsed at 1-s intervals. The fence allowed all other large herbivores except elephants to pass under the wire. No giraffe were recorded in the area during this experiment so did not affect its outcome. Seedlings inside and outside the exclosure were matched for height at the start of the experiment. Measurements of plant height, stem diameter and condition were recorded monthly as in phase 1 experiment.

We continued phase 2 experiment until March 1989 when large branches of several study trees were chopped down by lodge staff. We nonetheless continued to monitor tree growth until December 1990 when the tangle of regeneration made further measurements impractical.

\section{Woodland restoration}

As a direct outcome of the experiments, we launched a woodland restoration project in the central park in 1985 as an extension of the phase 2 experiment. The purpose of the woodland restoration was threefold. First, to show that the experimental plots could be easily scaled up to provide a conservation refugia for woodland species of plants and animals that had become extinct or were disappearing in the park. Secondly, to restore seed production to avert the complete loss of A. xanthophloea and other woodland plants in the park. Thirdly, to screen off the clutter of lodge and staff housing at Ol Tukai that became an eyesore in the park when the woodlands died out in the 1970s. The Ol Tukai restoration project in itself was a test case for restoring other pockets of woodlands across the park.

With this in mind, we first expanded the phase 2 fence to an area of 250 ha around Ol Tukai in 1985. Three additional elephant exclusion plots were constructed around the lodges at Ol Tukai between 1990 and 1992. In 1995 all four plots were linked up to include an expanded contiguous woodland restoration plot of $1.6 \mathrm{~km}^{2}$.

As the restoration project encompassed the phase 2 project, we took the seedling growth in the experimental plot to represent the 250 ha restoration project as a whole.

\section{Results}

A \pm figure following the mean refers to the standard deviation of the mean in the following results.

\section{Phase 1 experiment}

The response of seedlings in the phase 1 experiment between 1981 and 1983 are given in Fig. 1. A two-way analysis of variance of all treatments combined (Table 2) showed large herbivores to be by far the most significant factor retarding seedling growth $(F=96.84, P<0.001)$. Insects contributed, but far less significantly $(F=18.43$, $P<0.001)$. Herb cover did not significantly slow down growth $(F=3.97, P>0.05)$. The dominant effect of large herbivores is shown in Fig. 1. The average height of protected seedlings increased significantly from $52.95 \pm$ 
Fig 1 Growth of acacia seedlings under eight different experimental treatments during phase 1

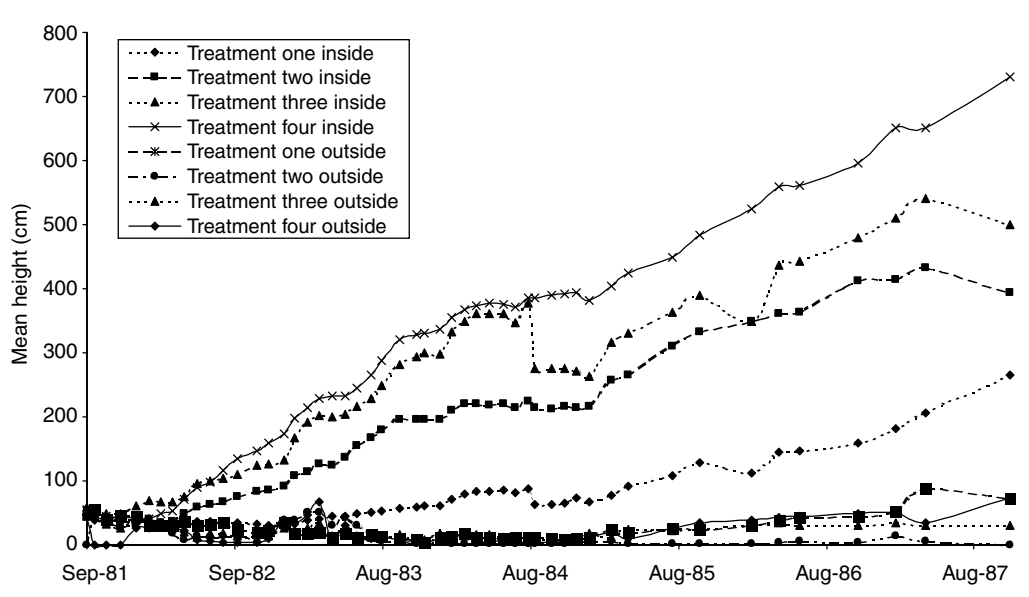

Table 2 Three-way analysis of variance results showing dependence of seedling growth on insect attacks, plant competitions, large herbivores (inside/outside exclosures) and the effect of interactions among all three variables

\begin{tabular}{llccccc}
\hline Main effects & df Effect & MS effect & df Error & MS error & $F$ value & $P$ level \\
\hline Insects & 1 & 78943.2 & 32 & 4282.725 & 18.433 & 0.000153 \\
$\quad$ Plants & 1 & 17015.6 & 32 & 4282.725 & 3.973 & 0.054817 \\
$\quad$ Inside/outside & 1 & 414733.2 & 32 & 4282.725 & 96.839 & 0.00000001 \\
Interactions & & & & & \\
$\quad$ Insects and plants & 1 & 6579.2 & 32 & 4282.725 & 1.536 & 0.224194 \\
Insects and inside/outside & 1 & 72165 & 32 & 4282.725 & 16.85 & 0.000261 \\
Plants and inside/outside & 1 & 22231.2 & 32 & 4282.725 & 5.191 & 0.0295 \\
$\quad$ Insects and Plants and inside/outside & 1 & 5546 & 32 & 4282.725 & 1.295 & 0.2635 \\
\hline
\end{tabular}

Table 3 Three-way analysis of variance results of acacia maturation showing dependence of acacia maturation on insect attacks, plant competitors and large herbivores (inside/outside exclosures) and the effect of interactions among all three variables

\begin{tabular}{llrrrrr}
\hline Main Effects & df Effect & MS effect & df Error & MS error & $F$ value & $P$ level \\
\hline Insects & 1 & 5953.6 & 32 & 1718.625 & 3.4642 & 0.07192 \\
Plants & 1 & 3132.9 & 32 & 1718.625 & 1.8229 & 0.18644 \\
$\quad$ Inside/outside & 1 & 417384.4 & 32 & 1718.625 & 242.8598 & $1 \mathrm{E}-08$ \\
Interactions & & & & & \\
$\quad$ Insects and plants & 1 & 13104.4 & 32 & 1718.625 & 7.6249 & 0.009454 \\
Insects and inside/outside & 1 & 1392.4 & 32 & 1718.625 & 0.8102 & 0.37479 \\
Plants and inside/outside & 1 & 4040.1 & 32 & 1718.625 & 2.3508 & 0.135049 \\
Insects and plants and inside/outside & 1 & 5569.6 & 32 & 1718.625 & 3.2407 & 0.081263 \\
\hline
\end{tabular}

12.72 to $237.22 \pm 117.84 \mathrm{~cm}(t=6.96, \quad P<0.001)$. Exposed seedlings shrank significantly from $48.7 \pm 13.4$ to $9.85 \pm 10.62 \mathrm{~cm}(t=10.28, P<0.001)$.

Phase 1 results extended to 1988 showed an even greater impact of large herbivores: by maturity, the effect of large herbivore alone was significant $(F=242.86$, $P<0.001$, Table 3). Thus, while caterpillars and perhaps herb cover slow early growth, they do not prevent woodland recovery.

The results of seedling growth in stem diameter give a similar picture. Between 1981 and 1983, stem diameter of seedlings protected from large herbivores grew significantly from $1.15 \pm 0.49$ to $5.06 \pm 2.32 \mathrm{~cm}(t=-7.39$, $P<0.001$. Seedlings exposed to large herbivores showed 
no significant change [initial diameter $1.3 \pm 0.57$, end diameter $0.95 \pm 1.23(t=1.15, P>0.05)]$.

The results of seedling mortality further reinforce the findings so far. In the first 2 years, two of twenty (10\%) died inside the exclosure compared with eight of twenty $(40 \%)$ outside, a highly significant difference $(t=-10.48$, $P<001)$. All mortality in the exposed plot was attributed to seedlings plucked to root level by elephants. Few seedlings survived plucking more than a few times.

Phase 2 experiment

In the phase 2 experiment, the high-level exclosure narrowed down the impact of large herbivores to elephants alone. Seedlings protected from elephants but exposed to all other large herbivores grew vigorously (Fig. 2) from $53 \pm 11.6 \mathrm{~cm}$ at the start of the experiment in 1985 to $311 \pm 83.2 \mathrm{~cm}$ at the end of the experiment in 1989 $(t=-14.0, P<0.001)$. Seedlings exposed to elephants in the control plot, on the other hand, showed no significant growth $(53 \pm 11.9 \mathrm{~cm}$ in $1985,55 \pm 45.6 \mathrm{~cm}$ in 1989 ; $t=0.21, P>0.05)$. As in phase 1 experiment, browsed seedlings never exceeded the height of the herb layer for more than a brief interval (Figs 1 and 2). By December 1990, the average height of the protected trees was $7 \mathrm{~m}$ (the tallest over $10 \mathrm{~m}$ ) and many had flowered and fruited.
Seedling mortality was $40 \%$ ( 8 of 20 ) in the presence of elephants and nil (0 of 20) in the absence of elephants $(t=-26.01, P<0.5)$.

\section{Interaction among treatments}

There was a significant negative interaction between large herbivores and insects $(F=16.85, P<0.001)$ in the phase 1 experiment between 1981 and 1983 (Table 2). This was due to the absence of both leaves and caterpillars on the large number of seedlings stripped by large herbivores, often to root level. There was also a significant negative interaction between large herbivores and herb cover $(F=5.20, P<0.05)$. We attributed this interaction to the greater height of seedlings under herb cover $(21.0 \pm 12.2)$ than in clipped down plots $(15.7 \pm 15.9, \quad F=5.67$, $\mathrm{n}=164, \mathrm{P}<0.018)$. Therefore, despite the greater leaf area on clipped-down plots $(F=11.51, P<0.001)$ that would ordinarily promote faster growth, exposed seedlings were browsed shorter than seedlings in the dense herb layer due to their greater vulnerability to browsers.

The impact of large herbivore predation on seedling growth was so dominant that it masked subtler effects and the interaction of invertebrate browsers and plant competitors. The subordinate effects and interactions can be demonstrated by comparing seedling growth in and

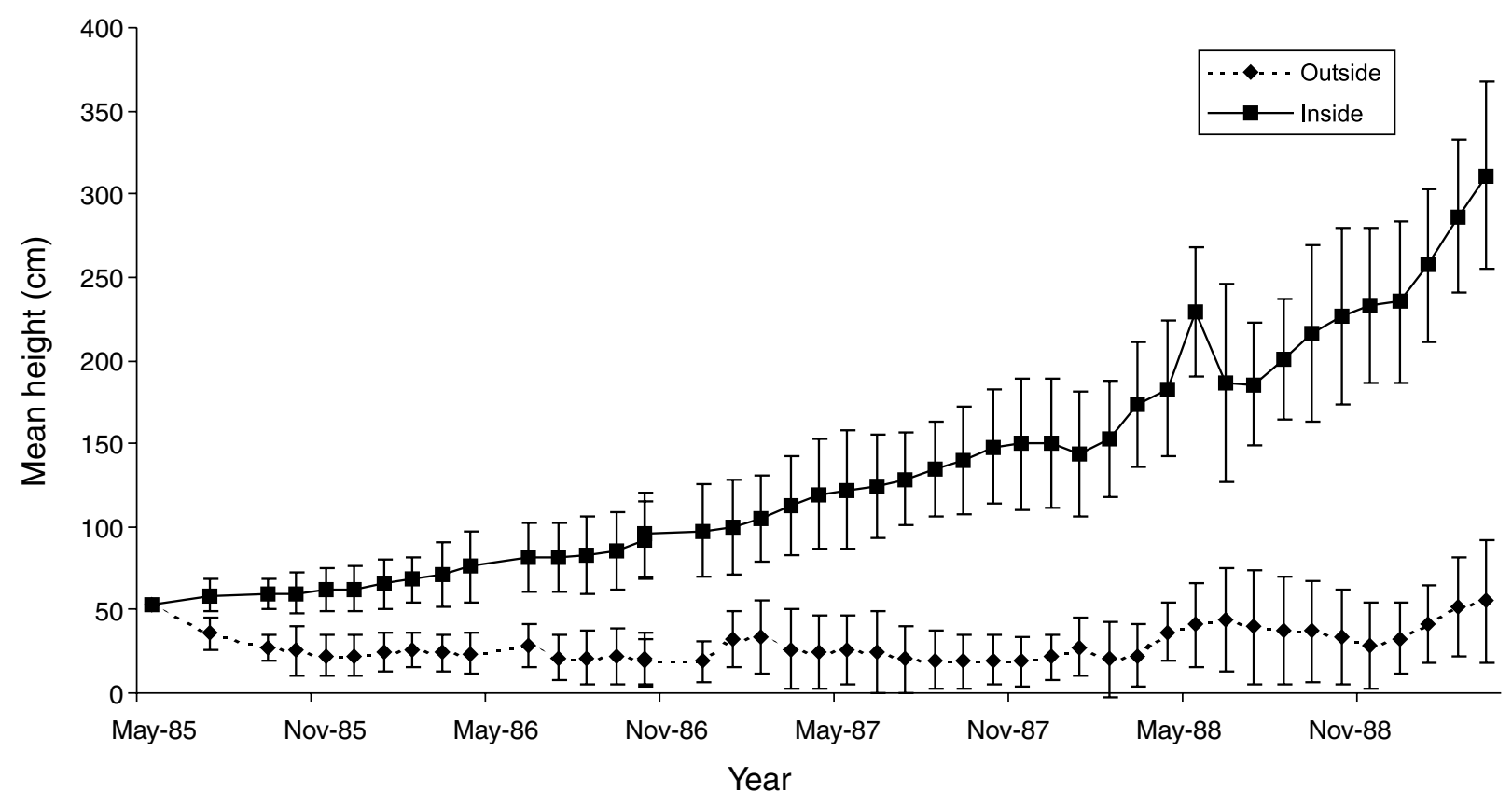

Fig 2 Growth of acacia seedlings in and outside a large herbivore exclosure 
Table 4 Two-way analysis of variance comparing seedling growth in and outside an elephant exclosure

\begin{tabular}{lrrrrrr}
\hline Variables & df Effect & Ms effect & df Error & Ms error & $F$ value & $P$ value \\
\hline \multicolumn{2}{l}{ Without Elephants } & & & & & \\
$\quad$ Insects & 1 & 151032.2 & 16 & 8448.55 & 17.877 & 0.0001 \\
$\quad$ Plants & 1 & 39072.8 & 16 & 8448.55 & 4.625 & 0.0471 \\
$\quad$ Interaction & 1 & 12103.2 & 16 & 8448.55 & 1.433 & 0.2488 \\
With Elephants & & & & & & \\
$\quad$ Insects & 1 & 76.05 & 16 & 116.9 & 0.651 & 0.4317 \\
$\quad$ Plants & 1 & 174.05 & 16 & 116.9 & 1.489 & 0.24 \\
$\quad$ Interaction & 1 & 22.05 & 16 & 116.9 & 0.189 & 0.6699 \\
\hline
\end{tabular}

outside the exclosure (Fig. 1). A two-way ANOVA of seedlings growth outside the exclosure (Table 4) shows no significant effect of either insects $(F=0.65, P>0.1)$ or plant competitors $(F=1.49, P>0.1)$. A two-way ANOVA inside the exclosure, in contrast, shows a significant effect of insects $(F=17.89, P<0.001)$ and plant competitors $(F=4.63, P<0.05)$.

Insects had a greater impact on growth than plant competitors. This can be shown by the significantly slower seedling growth in the presence of insects and absence of plant competitors (treatment 3), compared with the absence of insects and presence of plant competitors (treatment 2$)(t=-3.21, P<0.01)$.

The overall order of growth rates bears out the foregoing results on the relative importance of elephants, insects and herb cover (Fig. 1). No growth occurred in the presence of large herbivores. In the absence of large herbivores, seedlings grew strongest in the absence of both invertebrate and plant competitors (treatment 4), slowest in the presence of both (treatment 1), and at intermediate levels where one or the other treatments was absent, with insects having a bigger impact (treatment 2) than plant competitors (treatment 3).

There was also a positive interaction between herb cover and invertebrate activity in the absence of elephants. Caterpillars, measured by web activity, were far more common on seedlings buried in the herb layer than on seedlings highly visible on clipped down plots $(F=7.98$, $P<0.01$ ). From field observations, we concluded that the high incidence of caterpillars on seedlings hidden in the herb layer is explained by the greater ease with which birds kill caterpillars on exposed seedlings.

\section{Woodland restoration project}

The woodland restoration project tracked seedling growth and maturation in the phase 2 experiment between 1985 and 1990. By then dense woodland was reestablished throughout the 250 ha restoration site. The recolonization began spreading throughout the contiguous $1.6 \mathrm{~km}^{2}$ Ol Tukai restoration area between 1990 and 1992. By November 2001 the woodlands covered most of the area, with new seedlings emerging and growing in the remaining open patches over the entire 16-year period from 1985.

\section{A test of theories}

The experimental results offer a test of the four theories of woodland loss in Amboseli National Park.

\section{Overgrazing theory}

Contrary to prediction, no regeneration occurred in the controls, despite the exclusion of livestock from the control plots between 1981 and 1990. In fact by 2001 no recruitment has occurred anywhere in vicinity of Ol Tukai outside the exclosures, despite livestock being excluded from the area since the early 1960s when a livestock-free zone was established by the Kajiado County Council.

\section{Pathogen/pest theories}

As the fence did not exclude micro-organisms or invertebrates, the pathogen/pest theory cannot explain the regeneration of seedlings and survival of adult trees inside the exclosure but not outside.

\section{Climatic theories}

The growth and survival of acacias inside but not outside the exclosure similarly discounts Western \& van Praet's (1973) and Young \& Lindsay's (1988) climate-related theories. Neither theory can explain the woodland recov- 
ery in small exclosures without evidence of recovery across the park as a whole. Further evidence reinforces the rejection of climatic theories.

Salinity theory. Western and van Praet's salinity hypothesis can, ironically, be rejected from a reanalysis of their original data. In proposing salt levels as the cause of woodland loss, they noted that tree mortality was highly correlated with both soil salinity and elephant damage (Western, 1973). However, they did not do a partial correlation to look at the independent effects. A partial correlation analysis of their original data collected in 1970 shows no significant relationship between tree condition and salinity when the effects of elephants are held constant $(r=-0.41, \mathrm{n}=18, P>0.05)$ but a highly significant correlation with elephant damage when salinity is held constant $(r=0.59, \mathrm{n}=18, P<0.001)$. We resampled the same plots in 1990 to test the climate and elephant theories during a wetter period and found the results even clearer. The partial correlation for elephant damage was, once again, highly significant $(r=0.60, P<0.001)$. A partial correlation for salinity, on the other hand, showed no significance $(r=0.04, P<0.1)$.

Demographic theory. Contrary to the demographic theory of episodic growth and senescence caused by rainfall fluctuations (Young \& Lindsay, 1988), tree regeneration occurred continuously in the exclosure and restoration plots from 1981 to 2002 and outside the park from the mid-1970s onwards (see below).

Herbivory theory. The herbivory hypothesis predicts that acacia seedlings will grow in the absence of browsers but not in their presence. The phase 1 experiment is consistent with this hypothesis. Seedlings grew rapidly when browsers were excluded but remained stunted in unprotected controls. The phase 2 experiment narrowed the candidate browsers yet further. Seedlings protected from elephants but exposed to all other large herbivores grew to maturity within 7 years. Invertebrates did not prevent woodland recovery. They did, however, slow growth in the early stages of seedling growth.

Data on seedling mortality reinforce the herbivory theory. In phase 1 of the experiment, nearly half the seedlings died on exposure to large herbivores. Close inspection showed that mortality occurred after seedlings were plucked to the roots by elephants. We regularly observed elephants systematically searching through the Cynodon dactylon grasslands and pulling up young seedlings on the control plots. The seedlings became more conspicuous and vulnerable to elephants once they emerge above the herb layer and their leaves grew thicker in the absence of impeding herb cover and caterpillar predation.

\section{Elephant and woodland dynamics}

The long-term experiments and restoration of a sizeable area of woodland in central Amboseli National Park demonstrate that elephants are the only factor preventing woodland recovery. Two further lines of evidence demonstrate that the experiments are not a localized aberration but reflect the impact of elephants in governing the dynamics of woodlands across the Amboseli basin.

First, five other exclosures constructed in the national park show similar tree recovery. These include a pumphouse fence constructed in the southern park in 1976, a nearby fence around Serena Lodge built in 1980, an exclosure at Olodare in the eastern park, an exclosure in Ol Tukai in the central park - both built in 1994 and a 250 ha restoration plot built at Olengaiya in the western park in 2001. Seedlings flourished at each site, spread across the former woodlands, as soon as they were enclosed. No regeneration has occurred anywhere else in the park during this 26-year period.

Secondly, woodlands immediately outside the park boundary began to recover in the mid-1970s, despite the continued loss of trees in the park. The recovery outside the park corresponded with a retreat of elephants into the park in the face of heavy poaching in the 1970s (Western \& Lindsay, 1984). Kangwana (1993) has shown that elephants avoid livestock where possible in Amboseli. Their normal aversion was heightened by the poaching and permanent settlement of Maasai close to the park (Western \& Lindsay, 1984; Western, 1994). By the mid1990s the woodlands outside the park were fully mature. However, elephants have begun to make inroads into the newly recovered woodlands as their range expands in response to their rising numbers and pressure on the park habitat.

The experimental results show a causal link between elephants and woodland dynamics lacking in earlier studies. Nonetheless, data collected at the time of rapid woodland collapse in the late 1960s did show a high correlation between tree condition and elephant damage when normalized for age class, and a high inverse correlation between tree density and elephant density 
(Western, 1973; Western \& van Praet, 1973). Coupled with later work showing a close link between elephant density and overall plant richness and large mammal community structure, Western (1989) concluded that elephants are a keystone species regulating the ecological dynamics and biological diversity of habitats in the Amboseli ecosystem.

Elephants may be the only factor preventing woodland regeneration, but the experiments point to invertebrate browsers and herbaceous cover moderating the rate of recovery and, perhaps, woodland density. The fastest seedling growth occurred when the sward was cropped short and caterpillars were absent. We therefore predict that heavy grazing promotes seedling growth. This prediction is borne out by the experimental results. Growth was significantly faster $(F=5.29, P<0.001)$ in the presence of large ungulates except elephants (phase 2 experiment) than over a comparable period in the absence of all large herbivores (phase 1 experiment). This result is consistent with the differential growth rates in the phase 1 where the fastest growth occurred where vegetation around seedlings was clipped short and caterpillars were absent, the slowest where both were present (Fig. 1).

From these results we conclude that the return of the migrants in the dry season (Western, 1975) accelerates seedling growth by cropping the herb layer short. But, as shown earlier, seedlings under these conditions are more retarded and suffer higher mortality than those hidden in the dense herb layer due to heavier elephant browsing. Thus, despite the catalysing impact of heavy grazing by wild herbivores, woodlands cannot recover in the park due to the high concentration of elephants.

Conditions outside the park, in contrast, favour woodland recovery. The year-round settlement and livestock grazing that has taken place since the mid-1970s creates ideal conditions for seedling growth - heavy grazing and few caterpillars. Furthermore, heavy human activity deters elephants, allowing woodlands to regenerate immediately outside the park. By the mid-1980s farmers at Namelok and Kimana east of Amboseli were hacking back fever tree thickets to plant crops.

These observation bear out Western \& van Praet (1973) finding that tree condition is inversely related to elephant density and positively related to livestock density. The findings also echo a Maasai saying that 'cattle create trees, elephants create grasslands' (Western, 1997). It is ironic that a strong argument for evicting the Maasai from the park was their alleged destruction of the woodlands.

\section{General discussion}

The experiments also highlight three interrelated questions touching on the ecology and conservation of woodlands in the savannas.

\section{Cause of woodland loss}

The woodland loss in Amboseli mirrors widespread losses across African savanna parks (Laws, 1970; Anderson \& Walker, 1974; Cumming et al., 1997). Several explanations have been advanced for such woodland decline, including climate, fire and herbivory (Caughley, 1976). Dublin et al. (1990) pointed out the difficulty in identifying the causal factors when multiple agencies and multiple stable states are involved, due to the lack of direct evidence to test predictions.

The Amboseli results show that it is possible to test competing hypothesis of habitat change and complex interactions using rigorous experimental design and longterm studies. Fire, a major factor in savanna woodlandgrassland cycles (Walter, 1973), is extremely rare and localized in Amboseli due to the patchy vegetation broken up by large alkaline pans (Western, 1973). Amboseli therefore provides a direct and compelling test that elephants alone can govern woodland dynamics in the absence of fire. Even where fire is present, elephant compression probably plays a primary role in driving woodlands to grasslands and in altering vegetation structure and richness in many African parks (Buechner \& Dawkins, 1961; Laws, 1970; Anderson \& Walker, 1974; Croze, 1974; Barnes, 1983; Owen-Smith, 1988; Dublin, 1995; Inamdar, 1996; Cumming et al., 1997).

\section{Biodiversity implications}

The loss of woodlands in Amboseli raises a number of points relevant to the conservation of biodiversity in savanna parks where elephant and human activity intersect.

It seems likely that pastoralists and elephants, both keystone species, played a joint role in creating and maintaining large-scale patch dynamics in the savannas. In this scenario, localized areas of woodland regeneration created by livestock depresses grass growth and grazer carrying capacity, forcing herds to search out better grasslands. In time elephants move into the thickets and gradually open up new grasslands. The oscillation of woodland and grassland habitats, mediated by elephants 
and livestock, has been likened to an ecological minuet creating a large-scale tapestry of habitats in Amboseli over many years (Western, 1997).

A breakdown in interpolated movements of livestock and elephants creates differential ecological impacts across the park boundary. Inside parks, high elephant densities are creating open grassland conditions, dominated by grazing ungulates. Outside, high livestock densities are creating dense woodlands favoured by browsing ungulates (Western, 1989). One consequence is that livestock cross into the park to feed on the new grasslands and elephants move outside to browse the new woodlands.

The new habitat configuration in Amboseli is mirrored regionally across eastern Africa. Here a fivefold differential in elephant densities in and outside parks due to human disturbance is promoting grasslands inside protected areas and woody invasion outside. The breakdown of habitat patchiness through segregation effects has far reaching implications for plant dynamics and biodiversity (Western \& Gichohi, 1993). There is already evidence that the outcome is creating a predominantly grazing community inside parks and browsing community outside (Western, 1989).

The loss of woodlands seen in broader taxonomic terms is likely to foreshadow even larger losses of biodiversity in parks. Cumming et al. (1997), in one of the few studies aimed at measuring wider taxonomic changes, showed that bird and ant richness was significantly higher in intact than elephant-degraded woodlands.

Given that parks are increasingly seen as refuges for biodiversity as a whole, woodland loss carries large policy implications. With woodlands being depleted by humans for agricultural development (Cumming et al., 1997), protected areas become all the more significant in preserving them. Yet the public is loath to regulate compressed elephant populations destroying woodlands inside parks (Cumming et al. (1997). How then can the conundrum of conserving biological diversity and viable elephant populations be resolved if not by management of some form? As we discuss below, protection of woodland refugia within parks may be an essential step in protecting enough habitat and seed bank to halt and reverse biodiversity loss.

\section{Reversibility}

The Amboseli experiments show that the woodland loss in the park is reversible. But even where reversible, the continued loss of habitat, seedlings and ultimately seed reserves raises the risk of extinction to woodland-dependent species and entire habitats. The longer the recruitment gap created by over-browsing, the lower the seed reserves will sink and the longer recolonization will take. In the case of Amboseli, even the remaining fever tree woodlands outside the park are disappearing fast as elephants expand their range. The establishment of woodland refugia therefore ensures that founder populations and seed reserves are maintained for future recolonization.

\section{Acknowledgements}

We wish to thank the Wildlife Conservation Society for the long-term support of the Amboseli Research and Conservation Program. We also thank the Kenya Wildlife Service for their support. Samuel Kamau assisted us with the analysis and the African Conservation Centre with logistical support. Finally, we wish to thank Shirley Strum for her helpful comments.

\section{References}

Anderson, G.D. \& WALKER, BH. (1974) Vegetation composition and elephant damage in the Sengwa Wildlife Research Area. Rhodesia J. South. Afr. Wildl. Manage. Assoc. 4, 1-4.

AnONYmous (1963) Amboseli faces cattle invasion. Afr. Wildl. News 1.

BARNES, R.F.W. (1983) Effects of elephant browsing on woodlands in a Tanzanian National Park: measurements, models and management. J. Appl. Ecol. 20, 521-540.

Buechner, H.K. \& DAWKins, H.C. (1961) Vegetation change induced by elephants and fire in Murchison Falls National park, Uganda. Ecology 42, 752-766.

CAughley, G. (1976) The elephant problem: an alternative hypothesis. East Afr. Wildl. J. 14, 265-283.

CRoze, H. (1974) The Seronera bull problem. 11. The trees. East Afr. Wildl. J. 12, 1-27.

Cumming, D.H.M., Fenton, M.B., Rautenback, I.L., Taylor, R.D., Cumming, G.S., Cumming, M.S., Dunlop, J.M., Ford, A.G., Hovorka, M.D., Johnston, D.S., Kalcounis, M., Mahlangu, Z. \& PorTFors, C.V.R. (1997) Elephants, woodlands and biodiversity in southern Africa. S. Afr. J. Sci. 93, 231-236.

Dublin, H.T. (1995) Vegetation dynamics in the Serengeti-Mara ecosystem: the role of elephants, fire and other factors. In: Serengeti II: Dynamics, Management and Conservation of an Ecosystem (Eds A. R. E. Sinclair and M. NorTon-Griffith). University of Chicago Press, Chicago, IL.

Dublin, H.T., Sinclair, A.R.E. \& McGlade, J. (1990) Elephants and fire as causes of multiple stable states in the Serengeti Mara woodlands. J. Anim. Ecol. 59, 1147-1164. 
Huntley, B.J. (1982) Southern African savannas. In: Ecology of Tropical Savannas (Eds B. J. HunTLEY and B. H. WALKER). SpringerVerlag, New York, Berlin.

INAMDAR, A. (1996) The ecological consequences of elephant depletion. $\mathrm{PhD}$ dissertation, University of Cambridge, Cambridge, UK.

Jewell, P.A. and Holt, S. (Eds) (1981) The Problems of Locally Abundant Wild Mammals. Academic Press, New York.

Kangwana, K. (1993) Elephants and Maasai: conflicts and conservation in Amboseli, Kenya. PhD dissertation, University of Cambridge, Cambridge, UK.

LAws, R.M. (1970) Elephants as agents of landscape change in East Africa. Oikos 21, 1-15.

LAWS, R.M., PARKER, I.S.C. \& JoHnstone, R.C.B. (1975) Elephants and their Habitats. Clarendon Press, Oxford.

LINDSAY, K.W. (1994) Feeding ecology and population demography of African elephants in Amboseli, Kenya. PhD dissertation, University of Cambridge, Cambridge, UK.

OWEN-SMith, R.N. (1988) Megaherbivores: the Influence of Very Large Body Size on Ecology. Cambridge University Press, Cambridge, UK.

Walter, H. (1973) Vegetation of the Earth in Relation to Climate and Eco-Physiological Conditions. Springer-Verlag, NY, USA.

WesteRn, D. (1973) The structure, dynamics and changes of the Amboseli ecosystem. PhD dissertation, University of Nairobi, Nairobi, Kenya.
Western, D. (1975) Water availability and its influence on the structure and dynamics of a savanna large mammal community. East Afr. Wildl. J. 13, 256-286.

WESTERn, D. (1989) The ecological role of elephants in Africa. Pachyderm 12, 42-45.

Western, D. (1994) Ecosystem conservation and rural development. In: Natural Connections: Perspective in Community-Based Conservation (Eds D. Western, M. Wright and S. C. STRum). Island Press, Washington, DC.

Western, D. \& GichoHI, H. 1993. Segregation effects and the impoverishment of savanna parks: the case for ecosystem viability analysis. Afr. J. Ecol. 31, 269-281.

Western, D. \& Lindsay, K.W. (1984) Seasonal herd dynamics of a savanna elephant population. Afr. J. Ecol. 22, 229-244.

Western, D. \& van Praet, C. (1973) Cyclical changes in the habitat and climate of an East African ecosystem. Nature 241, 104-106.

Western, D. \& Sindiyo, D.M. (1972) The status of the Amboseli rhino population. East Afr. Wildl. J. 10, 43-57.

Young, T.P. \& LindSAY, K.W. (1988) Role of even-age population structure in the disappearance of Acacia xanthophloea woodlands. Afr. J. Ecol. 26, 69-72.

(Manuscript accepted 26 November 2003) 